\title{
Hydrogen Refueling Stations: Safety and Sustainability
}

\author{
Mario Pagliaro*,a and Adolfo Iulianelli ${ }^{b}$ \\ ${ }^{a}$ Istituto per lo Studio dei Materiali Nanostrutturati, CNR, via U. La Malfa 153, 90146 Palermo, Italy \\ ${ }^{b}$ Istituto di Tecnologia delle Membrane, CNR, via P. Bucci, Cubo 17/C, Università degli Studi della Calabria, \\ 87036 Rende, Italy \\ Email: mario.pagliaro@cnr.it (M. P.)
}

\begin{abstract}
In June 2019, two hydrogen-related accidents occurred independently at a hydrogen refueling station in Norway and at a chemical plant in California while filling a truck due to supply the fuel at stations in California. The accidents raised questions about the safety and reliability of hydrogen for powering both fuel cell electric vehicles and buildings. As a preventive measure, for instance, Germany and Norway closed the hydrogen refueling stations from the same manufacturer of Norway accident, while the hydrogen manufacturer in California ceased supply of hydrogen fuel for more than three months. It is significant to review the outcomes of the two accidents in the context of the emerging solar economy, in which $\mathrm{H}_{2}$ is locally produced from water via simple electrolysis using renewable electricity. This study provides an insight and selected recommendations aiming at hydrogen companies, professionals and trainers and educators in renewable energy and clean technology.
\end{abstract}

Keywords hydrogen refueling station, hydrogen safety, hydrogen energy, water electrolysis

\section{Introduction}

Thousands of internal combustion engine vehicles (ICEVs) catch fire across the world's roads and highways every day. Only in the United States, the 2006-2010 period saw 287,000 vehicle fires translating (with 253 million cars on U.S. roads) into about 1 fire per 880 vehicles. ${ }^{[1]}$ Though at much lower rate, petrol refueling stations also regularly catch fire yearly across the world. Recent examples span from a petrol station in Virginia, USA, exploded in May 2019, ${ }^{[2]}$ through another in Jieyang, China, in April 2019. ${ }^{[3]}$

Gasoline in the air at ambient temperature and atmospheric pressure is flammable at a lower concentration limit of $1.2 \%$, a volume concentration easily reached $(7.1 \%$ is gasoline's upper explosive limit). ${ }^{[4]}$ Furthermore, gasoline vapor is heavier than air. If released, it accumulates at ground level where accidental ignition presents a clear danger.

Similarly, in 2015 over 18 million natural gas vehicles across more than 90 countries used compressed natural gas (CNG) as fuel dispensed according to various standards. Methane in the air has 5\% lower explosive limit and 15\% upper explosive limit. Only in Pakistan, some 55 CNG-related accidents conduced to over 250 casualties leading scholars to conclude that CNG vehicle accidents are "a major threat to life in Pakistan". ${ }^{[5]}$ Root cause analysis of the aforementioned 55 accidents points to low-quality CNG system material (cylinder), design and installation of the refueling station, maintenance system, lack of strict government CNG vehicle safety regulations and driver negligence. ${ }^{[5]}$

Safety laws and standards are continuously improved and enforced so as to prevent risk and minimize the consequences of accidents for both ICE vehicles and petrol and CNG refueling stations, while the global number of vehicles and refueling stations continues to grow thanks to rapid economic development of huge and highly populated nations such as China, India and Brazil.

Even body static generated through vehicle re-entry, refueling is the frequent cause of numerous unexplained petrol station fires caused by the discharge of static electricity from the body. ${ }^{[6,7]}$

In this context, battery electric vehicles (BEVs) using Li-ion batteries have lately emerged as the first ever alternative to internal combustion vehicles adopted on significantly large scale. ${ }^{[8]}$ The main limitation of BEVs is the prolonged time needed for recharging battery packs that nowadays regularly exceed the $40 \mathrm{kWh}$ capacity, and often much more. Moreover, lack of investment in Li-ion battery plants in most world's countries beyond China, Japan, South Korea and partly the USA has created a serious supply bottleneck, which is limiting industrial production of BEVs in all countries beyond those mentioned above.

Adding the required "portfolio" solutions to have technological diversity, new generation hydrogen fuel cell electric vehicles (FCEVs) address the aforementioned limitations is a surprising complementary fashion, even if their current production levels are dwarfed by BEVs. For instance, the carmaker manufacturing the world's top selling FC car, produced slightly more than 6,000 cars in its dedicated plant in Japan in 2018. The same company announced plans to upscale production to $30,000 / a$ "post 2020", ${ }^{[9]}$ namely a figure close to the amount of BEVs sold in China by a single large BEV manufacturer only in the course of the month of April 2019 (22,735 BEVs). ${ }^{[10]}$

Hydrogen FCEVs use hydrogen of high purity (> 99.99\%) stored at high pressure (350 or 700 bar) in today's cylinders comprised of composite material. Compressed hydrogen provides FC electric vehicles with uniquely high amounts of energy, and thus autonomy, not only in the case of cars, but also of much heavier trains and ships. Indeed, the world's two hydrogen-powered electric trains with roof-mounted hydrogen tanks entered service in Germany's regional train lines in September $2018 .^{[8]}$

More than one hundred hydrogen FC trains have already been commissioned in several countries, with only one manufactured having received an order in Germany for 27 new hydrogen-powered trains. ${ }^{[11]}$ Similarly, the first hydrogen-powered heavy duty trucks are up to be commercialized by several 
manufacturers in Japan, South Korea, and in the USA.

The aforementioned around $€ 500$ million order for fleet of 27 fuel cell trains in Germany includes the construction of the hydrogen refueling station (HRS), located near a chemical industrial park where $\mathrm{H}_{2}$ is mostly obtained via methane steam reforming. ${ }^{[12]}$

Hydrogen is two to three times less flammable than gasoline in the air (4\% lower concentration limit for $\mathrm{H}_{2}$ vs. $1.4 \%$ ), but it has a wide flammable and explosive range (up to $75 \%$ in air). ${ }^{[4]}$

In June 2019, two hydrogen-related accidents occurred independently at a hydrogen refueling station in Norway and at a chemical plant in California while filling a truck due to supply the fuel at stations in California. The accidents raised questions about the safety and reliability of hydrogen for powering both fuel cell electric vehicles and buildings. As a preventive measure, for instance, Germany and Norway closed the hydrogen refueling stations from the same manufacturer of Norway's accident, while the hydrogen manufacturer in California stopped supply of hydrogen fuel to the state's HRS networks for more than three months. It is significant to review the outcomes of the two accidents in the context of the emerging solar economy, in which $\mathrm{H}_{2}$ is locally produced from water via simple electrolysis using renewable electricity. This study provides an insight and selected recommendations aiming at hydrogen companies, professionals and educators in renewable energy and clean technology.

\section{Incidents and Accidents at Hydrogen Refueling Stations}

Refueling compressed hydrogen is similar to refueling compressed natural gas, even though the hydrogen refueling technology is considerably more advanced.

In Japan, the world's leading country in terms of HRS number (96 public stations by the end of 2018) ${ }^{[13]}$ the incidents and accidents are classified into six categories:

(i) Leakage I: leakage due to the damage and fracture of main bodies of apparatuses and pipes (including welded parts); (ii) Leakage II: leakage from flanges, valves, and seals (including deteriorated nonmetallic seals); (iii) Leakage III: leakage due to human error and external impact; (iv) Explosion and fire; (v) Burst and fracture; (vi) Others.

A thorough analysis of incidents and accidents occurred at Japan's at hydrogen refueling stations between 2005 and 2014 shows that out of 21 incidents and accidents, 14 were in the form of "Leakage II", namely leakage from flanges, valves, and seals (including deteriorated nonmetallic seals), with most said leak incidents caused by inadequate torque and sealing. ${ }^{[14]}$ The only explosion, recorded in a highly compressed hydrogen energy generator, was due to a design error, and the single burst, in a filling hose, again due to design error (fatigue). ${ }^{[14]}$

The aforementioned analysis of incidents and accidents at Japan's HRS, led scholars to conclude that to address the main cause of leakage I, poorly planned fatigue, it is very important to adequately consider the usage environment in the design. Since leakage II is mostly caused by screw joints, welded joints of suitable strength and reduction in pipe thickness are recommended. Finally, since the main cause of leakage III is human error, safety measures should be developed to prevent human error by FCEV users. ${ }^{[14]}$

On June 10 2019, an unmanned HRS in Norway burned for almost $3 \mathrm{~h}$, following ignition and an initial explosion. Neither the low pressure nor the high pressure hydrogen tanks exploded. "It was pretty hot. We saw three other cars on the road where the pressure from the explosion had triggered their airbag." ${ }^{[15]}$ a witness said. There was "no report of injuries due to the explosion" with "two people hospitalised due to injuries caused by car airbags triggered by the shock wave of the explosion". ${ }^{[15]}$

Watching the brief (36 s) video realized by the same witness from a passing car later published online by Norwegian Broadcasting Corporation, ${ }^{[16]}$ shows from a missing wall out of several comprising the fire/pressure wall surrounding the hydrogen production unit the horizontal flames resulting from the quick combustion of leaking hydrogen.

The $\mathrm{H}_{2}$ production unit in question includes a containerized, pressurized alkaline electrolyzer, the electrolyzer control and power supply, the low and the high pressure hydrogen storage units and a low pressure transport unit. ${ }^{[17]}$

Following preliminary technical investigation, the safety consultancy hired by the owners and suppliers of the Norway's HRS concluded that neither the electrolyzer nor the dispenser used by customers was involved in the incident. "We can say with certainty." The consultants claimed, "That the leak started in the high-pressure storage unit, and we are now carrying out investigations to understand the detailed mechanisms of the leakage as well as what caused the ignition". ${ }^{[17]}$

On June 27 2019, the HRS manufacturer announced that the root cause of the incident had been identified as an assembly error of a specific plug in a hydrogen tank in the high-pressure storage unit. ${ }^{[18]}$ This led to leakage of $\mathrm{H}_{2}$ gas in the surrounding air. Hydrogen is the lightest chemical element (the gas is 14 times lighter than air). If released at normal ambient temperatures, it disperses quickly rising into the atmosphere at a rate of about $20 \mathrm{~m} / \mathrm{s}$, without reaching the $4 \%$ concentration which is its lower flammability limit. Indeed, investigations into the specific source of ignition three months after the incident were reported "to continue". ${ }^{[19]}$

In any case, there would have been no leakage in Norway without a human error: "Due to human error, the inner bolts of the plug had not been adequately torqued". ${ }^{[18,19]}$

In other words, regardless of clear specifications for the proper torqueing of bolts in the high-pressure storage unit, in this specific case the torqueing requirements were not met due to human error. To prevent the incident to happen again, the HRS manufacturer has introduced a dual-witness torque procedure, whereby first one fitter torques to nominal torque in a 3-step procedure and marks each specific bolt with a green line after torqueing. Afterwards, a second fitter performs a control by re-torqueing each bolt, marking it with a red line ${ }^{[18,19]}$

\section{Shifting from Petrol and Natural Gas Refueling Model}

Critics of hydrogen fuel cell vehicles argue that the hydrogen refueling station would replicate the model of the petrol and compressed natural gas refueling station; ${ }^{[20]}$ with HRS receiving gaseous or liquid hydrogen from hydrogen "refineries" similarly to what happens with fossil fuel stations regularly supplied with gasoline and diesel fuels by trucks commuting with oil refineries, or by natural gas via pipelines.

On the contrary, as anticipated in 2012 by Pagliaro and Konstandopoulos, ${ }^{[21]}$ hydrogen refueling stations will increasingly self-produce compressed $\mathrm{H}_{2}$ on-site using electricity self-gener- ated by today's low cost photovoltaic electricity (and via concentrated solar power in "sunbelt" countries), as well as from cheap wind and hydroelectric power available through the grid.

This is what happens for instance in the world's first off-grid hydrogen station in Sweden's Mariestad (Figure 1) producing 4 tonnes of $\mathrm{H}_{2}$ yearly using the electricity generated by the adjacent $250 \mathrm{~kW}$ photovoltaic park expected to provide (in southern Sweden) $250,000 \mathrm{kWh}$ per year with production concentrated 

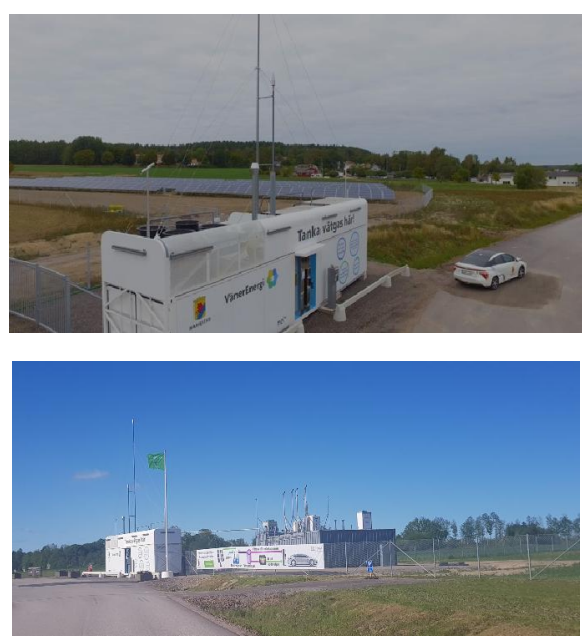

Figure 1 The off-grid solar hydrogen refueling station in Mariestad, Sweden. The PV park (top) supplies all the electricity needed to produce hydrogen. [Photo courtesy of Nilsson Energy]

between April and September. ${ }^{[22]}$

Renewable and emission-free hydrogen produced by splitting water into $\mathrm{H}_{2}$ and $\mathrm{O}_{2}$ in a containerized, pressurized alkaline electrolyzer system is further compressed and stored in 216 cylinders in composite material, from where it is used to refuel FC electric vehicles dispensing $\mathrm{H}_{2}$ compressed at 700 bar. The electrolyzer is capable to produce up to 40 tonnes of $\mathrm{H}_{2}$ per year, namely 10 times the current capacity anticipating forthcoming growth in production as the number of FCEVs in Sweden will shortly increase. Currently, as the number of FC vehicles in Sweden is still very low, part of the hydrogen produced at Mariestad's station is also used to regulate the grid thanks to a fuel cell connected to an inverter.

It is also remarkable that the HRS in Mariestad, firstly inaugurated in January 2017, originally used hydrogen supplied with truck in pressurized cylinders. However, the city and the regional utility company operating the station planned to make it the world's first off-grid HRS powered by solar energy only for on-site hydrogen generation, energy storage (both $\mathrm{H}_{2}$ storage and batteries) and fuel cells for power generation and back up for the solar based power supply.

The efficiency of the electrolytic process is high, ${ }^{[8]}$ and alkaline electrolysis is a reliable technology whose only limit for large-scale hydrogen manufacturing has been the high cost of electricity. Now that solar electricity can be produced at extremely low cost in huge amounts thanks to the photovoltaic technology, ${ }^{[23]}$ the route is open to its widespread adoption of this technology across the world, including developing regions and countries where adoption of BEVs is problematic due to grid scaling issues and coal-fired power production.

In brief, once electricity from sun, wind and water free energy sources is available in large amounts at low cost, the electrolytic production of hydrogen becomes convenient, even on the huge scale required for ammonia and fertilizer production. This has been demonstrated in practice by the $165 \mathrm{MW}$ electrolyzer installed at Egypt's Aswan dam in 1960 delivering 3.33 tonnes of $\mathrm{H}_{2} / \mathrm{h}$ on a $24 \mathrm{~h} / 7$ day operation basis to feed with hydrogen a 400 tonne/day ammonia production unit using low cost hydroelectric power. ${ }^{[24]}$

\section{Conclusions}

In general, the hydrogen refueling station is a safe, reliable and convenient technology. For example, in its first year of operation (to April 2017), one HRS in Denmark dispensed 900 $\mathrm{kg}$ of hydrogen with excellent reliability ( $98.2 \%$ availability) and no incident. ${ }^{[25]}$ The average hydrogen refuelling time for passenger FC cars (2-3 min) was comparable to that for conventional internal combustion engine vehicles.

Hydrogen, however, is a highly flammable gas due to its very wide flammability range (from $4 \%$ to $75 \%$ in air), to its very low ignition energy, and to the ease of leakage due to its light molecular weight $(2.016 \mathrm{~g} / \mathrm{mol}) .{ }^{[26]}$ Furthermore, $\mathrm{H}_{2}$ cannot be smelled and burns with an invisible flame.

Research aimed at further improving the safe utilization of hydrogen as a fuel at refueling stations and in hydrogen fuel cell electric vehicles actively continues across the world at corporate and academic research centres. Progress in the course of the last five years has been dramatic. For example, in 2018 a fuel cell sport utility vehicle manufactured in South Korea, storing onboard $\mathrm{H}_{2}$ pressurized at 690 bar in three pressurized cylinders, received the five-star (highest) car crash safety certification existing in Europe. ${ }^{[27]}$

It is instructive to learn that amid hydrogen safety research gaps identified in $2012,{ }^{[28]}$ ignition probability and its reliance on leakage characteristics, ${ }^{[29]}$ continued to be an unresolved item in hydrogen safety science. For this reason, the same scholars advocated "the involvement of chemistry as practiced by industrial chemists in the domain of chemical/process engineering" as well as the need for "the greater participation of chemistry researchers in the field of inherently safer design". [28]

It is also instructive to learn that research on the root causes of several accidents involving hydrogen fire and explosions in 215 events occurred between 1992 and 2008 recorded in France's ARIA public database found that "in over $70 \%$ of the cases organisational and human factors contribute to the deep-rooted causes of the accidents". ${ }^{[30]}$

Hydrogen is manufactured and used on a 150 million t/a scale in the petrochemical industry, with about half of it used to synthesize ammonia, but also to refine oil, and produce hydrogen peroxide. Accidents involving hydrogen in the chemical industry, regardless of its huge scale, are rare (low incident rate, with a small $4.6 \%$ proportion resulting in human life loss). ${ }^{[26]}$

However, and this is the first guideline emerging from the present study, as the global uptake of hydrogen as fuel of fuel cells powering vehicles, boats and buildings eventually unfolds across the world companies manufacturing water electrolysers and hydrogen refueling stations should increasingly focus on the "organisational and human factors"[30] mentioned above.

In other words, user safety problems for a technology that will be used on a daily bases by thousand of different persons with different cultures and educational backgrounds may soon emerge as a key issue on the road to widespread solar hydrogen uptake as ubiquitous energy carrier. A recent example from the $\mathrm{H}_{2}$ refueling station infrastructure in California, by far the world's leading market for FCEVs, reinforces this insight.

On June 1, 2019 (a Saturday), an explosion occurred in one of the main suppliers in northern California as a tanker truck was being filled with liquid hydrogen (later to be re-gasified at HRS for fueling hydrogen in fuel cell vehicles) obtained from methane steam reforming at a chemical plant in Santa Clara.

There was no injury, even though the explosion "shook buildings for miles in the San Francisco Bay Area, leaving many residents believing at first that they were experiencing an earthquake". ${ }^{[31]}$ Following the blast, delivery of $\mathrm{H}_{2}$ to several California's HRS stopped affecting fuel supply in the subsequent months. Three months after the accident, the hydrogen supplier was awaiting further inspections and direction from the authorities to be able to resume fueling and return to full operations. As a result, "of the 13 stations in northern California only a handful were found to be operational". ${ }^{[32]}$

Preliminary investigation turned out to be a human error as 


\section{Perspective}

well. In detail, "a hydrogen leak was detected during the trailer fill process $\cdots$ the fill should have been stopped and the vehicle placed out of service for maintenance to be performed by trained technicians at one of our maintenance locations. Instead, an employee attempted to perform maintenance on the process equipment without authorization. This resulted in a release of high pressure hydrogen and the subsequent fire". ${ }^{[3]}$

These outcomes reinforce the second and third main recommendations of the present study on having better training for the personnel as well as to switch to decentralized solar hydrogen production relying on self-generated photovoltaic electricity and water electrolysis.

Several multi MW water electrolysis plants to be fed with renewable electricity are currently under construction across the world, and many others will shortly follow. Shaping a larger number of students with a background in science, technology and engineering with updated knowledge on solar hydrogen energy science and technology, including hydrogen safety and energy management, is an urgent societal need to provide society with the young professionals needed to locally guide the global transition to the solar economy. ${ }^{[34-36]}$

\section{References}

[1] U.S. Vehicle Fire Problem, by Type of Vehicle 2006-2010 Annual Averages, https://www.nfpa.org/-/media/Files/News-and-Research/ Fire-statistics-and-reports/US-Fire-Problem/ostypeofvehicle.ashx.

[2] Police: Explosion and fire at Virginia gas station leaves three people dead, USA Today, 11 May 2019.

[3] Cheng, K. Man causes a huge explosion after forgetting to remove the gas hose and driving off with the pump at a petrol station, Daily Mail, 24 April 2019.

[4] Lower and upper explosive limits for flammable gases and vapors (LEL/UEL), Matheson Gas Prod. 2013, p. 22.

[5] Khan, M. I.; Yasmeen, T.; Khan, N. B. J. Braz. Soc. Mech. Sci. Eng. 2015, 38, 2481

[6] Burgess, A. Health Risk Soc. 2007, 9, 53.

[7] Coates, R. Review of Alleged Mobile Phone Incidents-The Fact, The Fiction and the Perception of Risk, in Institute of Petroleum, Technical Seminar Proceedings: Can Mobile Phone Communications Ignite Petroleum Vapour? Institute of Petroleum, London, 2003, pp. 43-49.

[8] Pagliaro, M.; Meneguzzo, F. J. Phys. Energy 2019, 1, 011001.

[9] Toyota, Toyota moves to expand mass-production of fuel cell stacks and hydrogen tanks towards ten-fold increase post-2020, 24 May 2018. See at the URL: https://global.toyota/en/newsroom/ corporate/22647198.html.

[10] Kane, M. In April 2019 BYD Increased Plug-In EV Car Sales By 73.5\%, insideevs.com, 27 May 2019.

[11] Alstom wins order for fleet of 27 fuel cell trains in Taunus region, Fuel Cell. Bull. 2019, 2019, 4.

[12] Schjølberg, I.; Calo, E.; van Dijk, E.; Ersöz, A.; Ochoa Fernandez, E.; Hulteberg, C.; Lieftink, D.; Nelsson, C.; Saint-Just, J.; Silversand, F.; Stauss, R.; Yasuda, I. Small-scale reformers for on-site hydrogen supply, Final report 2006-2011, International Energy Agency, Paris, 2012, pp. 1-148.

[13] TÜV SÜD, Highest increase of hydrogen refuelling stations in Germany worldwide in 2018 again, 15 February 2019. See at the URL: www.globenewswire.com/news-release/2019/02/15/1726095/0/en/Highest-increase-of-hydrogen-refuelling-stations-in-Germa ny-worldwide-in-2018-again.html.

[14] Sakamoto, J.; Sato, R.; Nakayama, J.; Kasai, N.; Shibutani, T.; Miyake, A. Int. J. Hydrog. Energy 2016, 41, 21564.

[15] Hydrogen fuel station explodes in Norway, carsales.com-au, 12
June 2019. See at URL: www.carsales.com.au/editorial/details/ hydrogen-fuel-station-explodes-in-norway-118954.

[16] Eksplosjon ved hydrogenstasjon, NRK Nyether, 10 June 2019. See at the URL: www.nrk.no/norge/eksplosjon-ved-hydrogenstasjon-1.14582914.

[17] Norway gas station explosion started with hydrogen leakage: preliminary report, Xinhua, 17 June 2019. See at the URL: www.xinhuanet.com/english/2019-06/17/c_138150858.htm.

[18] Nel ASA, Status and Q\&A regarding the Kjørbo incident, 27 June 2019. See at the URL: https://nelhydrogen.com/status-and-qaregarding-the-kjorbo-incident/.

[19] Løkke, J. A. The Kjørbo Incident, press conference, 28 June 2019. See at the URL: https://nelhydrogen.com/assets/uploads/2019/06/ 2019-06-28-Nel-ASA-Kjorbo-press-conference.pdf.

[20] Alter, L. Is hydrogen back in the energy picture? Or is it all just shilling for oil companies? treehugger.com, 13 November 2018. See at the URL: https://www.treehugger.com/clean-technology/ hydrogen-back-energy-picture-or-it-all-just-shilling-oil-companies. html.

[21] Pagliaro, M.; Konstandopoulos, A. G. Solar Hydrogen, RSC Publishing, Cambridge, 2012, pp. 1-39.

[22] Nilsson Energy, Off-grid solar powered refuelling station, 29 May 2019. See at the URL: https://nilssonenergy.com/portfolio-item/ solar-powered-refuelling-station/.

[23] Meneguzzo, F.; Ciriminna, R.; Albanese, L.; Pagliaro, M. Energy Sci. Eng. 2015, 3, 499.

[24] Braun, A. Electrochemical Energy Systems, De Gruyter, Berlin, 2019, p. 132.

[25] Speers, P. World Electr. Veh. J. 2018, 9, 2.

[26] Rigas, F.; Amyotte, P. Hydrogen Safety, CRC Press, Boca Raton, FL, 2012, pp. 217-228.

[27] Euro NCAP, Hyundai Nexo, 2018. See at the URL: www.euroncap. com/en/results/hyundai/nexo/33731.

[28] Rigas, F.; Amyotte, P. Chem. Eng. Trans. 2013, 31, 913.

[29] Pasman, H. J.; Rogers, W. J. J. Loss. Prev. Process Ind. 2010, 23, 697.

[30] BARPI, Accidentology involving hydrogen, Lyon: 2009. See at the URL: www.aria.developpement-durable.gouv.fr/wp-content/files_ mf/SY_hydrogen_GB_2009.pdf.

[31] Bergenson, A. Chemical plant explosion in California leaves hydrogen car drivers without fuel, Hydrogen Fuel News, 6 June 2019 See at the URL: http://www.hydrogenfuelnews.com/chemicalplant-explosion-in-california-leaves-hydrogen-car-drivers-without-f uel/8537653/.

[32] Acoba, P. NorCal $\mathrm{H}_{2}$ Shortage still ongoing three months after Santa Clara Air Products explosion, Tire Meets Road, 1 September 2019. See at the URL: https://tiremeetsroad.com/2019/09/01/ norcal-h2-shortage-still-ongoing-three-months-after-santa-clara-air -products-explosion/.

[33] Air Products, Update for Southern/Northern CA Hydrogen Fueling Customers, 28 June 2019. See at the URL: http://www.airproducts. com/APNews. aspx?fbclid=IwAR2ZT4TwOjxKpjunBMff3xdlojn6OX Doq41ekO6Ru9EB-CyrLE1336dEOGU.

[34] Ciriminna, R.; Meneguzzo, F.; Pecoraino, M.; Pagliaro, M. Renew. Sust. Energ. Rev. 2016, 63, 13.

[35] Bezdek, R. H. Renew. Energy Environ. Sustain. 2019, 4, 1.

[36] Ciriminna, R.; Pecoraino, M.; Meneguzzo, F.; Pagliaro, M. Energy Res. Soc. Sci. 2016, 21, 44. 